Quiñones-Llópiz, J. D., Rodríguez-Fourquet, C., Luppi, T., \& Farias, N. E. (2021). Size distribution and sex ratio between populations of the artisanal harvested land crab Cardisoma guanhumi (Decapoda: Gecarcinidae), with the estimation of relative growth and size at sexual maturity in Puerto Rico. Revista de Biología Tropical, 69(3), 8981003. https://doi.org/10.15517/rbt.v69i3.45570

https://doi.org/10.15517/rbt.v69i3.45570

\title{
Size distribution and sex ratio between populations of the artisanal harvested land crab Cardisoma guanhumi (Decapoda: Gecarcinidae), with the estimation of relative growth and size at sexual maturity in Puerto Rico
}

Jesús D. Quiñones-Llópiz ${ }^{*}$; (iD https://orcid.org/0000-0002-3533-5236

Concepción Rodríguez-Fourquet ${ }^{1}$; (D) https://orcid.org/0000-0001-7622-7381

Tomás Luppi²; (D) https://orcid.org/0000-0002-4959-5987

Nahuel E. Farias²; (iD https://orcid.org/0000-0001-5190-370X

1. Departamento de Biología, Universidad de Puerto Rico en Bayamón, Bayamón, Puerto Rico; jesus.quinones5@upr.edu (Correspondence*),concepcion.rodriguez@upr.edu

2. Laboratorio de Invertebrados, Instituto de Investigaciones Marinas y Costeras, Facultad de Ciencias Exactas y Naturales, Universidad Nacional de Mar del Plata - Consejo Nacional de Investigaciones Científicas y Técnicas, CC 1260, Funes 3350, CP 7600, Mar del Plata, Argentina; taluppi@mdp.edu.ar, nefarias@mdp.edu.ar

Received 29-I-2021. Corrected 16-VII-2021. Accepted 25-VIII-2021.

\begin{abstract}
Introduction: Knowledge of growth patterns, sex ratio, and sexual maturity are of importance to exploited populations. The land crab Cardisoma guanhumi is an artisanal and subsistence exploited species in Puerto Rico. However, the growth patterns and sexual maturity of the local populations are not known.

Objectives: This study has a double objective: (1) to compare the size and sex structure between populations and (2) to model the relative growth of structures related to reproduction to estimate the average size of morphometric sexual maturity (MSM) for both males and females.

Methods: A total of 2849 specimens were captured from nine dispersed populations on the island between 2001 and 2020. Carapace width (CW) was measured as an estimator of the absolute size of all individuals, together with the propodus length (PL) in males and the abdomen width in females (AW). Differences in length structure between sexes and populations were tested by applying goodness-of-fit tests based on Kernel Density Estimators (KDE). The relative growth pattern was modeled adjusting a spline from which the maximum of its second derivative was calculated as an estimator of the MSM, and bootstrapping was used to generate confidence intervals.

Results: Differences were found in size structures, between sexes, and between sites. Our estimates of morphometric sexual maturity resulted in a sexual maturity size for males between 57.9 and $79.0 \mathrm{~mm} \mathrm{CW}$, while in females, morphological maturity occurs between 43.8 to $51.5 \mathrm{~mm} \mathrm{CW}$.

Conclusions: We found inter-population differences in body size that can be attributed to differences in the history of changes of land use and the exploitation biased towards larger individuals, though differences in recruitment should also be considered. Current regulations in Puerto Rico protect female crabs but not to larger male crabs. The regulation establishes that crabs smaller than $64 \mathrm{~mm}$ carapace width cannot be captured, leaving immature male crabs over $64 \mathrm{~mm} \mathrm{CW}$ unprotected. We suggest considering different size limits depending on the sex of the crab. This will allow the full range of sizes where sexual maturity is reached to be protected, increasing the likelihood of the population's size to increase.
\end{abstract}

Key words: reproductive biology; juey; mangrove; land-use change; fisheries; management recommendations. 
Management of commercially exploited species heavily relies on regulatory tools that protects the fishery resources by recovering overfished stocks, protecting fish habitat, regulating fishing gears, and minimizing bycatch (Magnuson-Stevens Fishery Conservation and Management Act, 2014). But to be effective, such regulations should be supported by reliable, up-to-date population-level estimations of the ecological and life-history parameters involved coupled to the ecosystem and human interactions (Pikitch et al. 2004; Townsend, 2019). In crustacean fisheries, the establishment of a legal minimum size and bans on females catching are the instruments traditionally applied, but often with no previous studies on the local populations to support it (Olson et al., 2018). Accurate estimation of the size range at which most individuals reach maturity is fundamental to set minimum legal sizes for extraction with the aim of leaving a portion of the population to reproduce at least once before being harvested. Particularly in crabs, the determination of maturity has been based on changes in molt increments, gonad development, detection of spermatophores in males and females or even size-specific behaviors, but by far the most used criterium is the identification of changes in the relative growth of different body parts known to be under sexual or fecundity selection, i.e., secondary sexual traits (Farias et al., 2020; Hartnoll, 1978; Lovett \& Felder, 1989). The determination of maturity based on morphological changes termed "morphometric maturity" requires the proper analyses of the relative growth trajectories to detect significant artifact-free changes in body shape that mark the onset of maturity. There are several alternative methods to perform these analyses, each with its pros and cons (Farias et al., 2014; Farias et al., 2020; Hartnoll, 2012). All methods are based on the same reasoning that if there is one conspicuous change in the shape of a body part known to be involved in reproduction, such change should reflect the onset of sexual maturity (or the socalled 'size at morphometric maturity' since it was estimated based in morphometric data).
The typical body parts used for this aim are the male claws involved in the intra-sex competition for mating, courtship, and pair handling during copula, and the female abdomen, which widens through the ontogeny to protect and carry the eggs until spawning (Hartnoll, 2012).

Cardisoma guanhumi is a land crab species that inhabits the coastal forests, mangroves, wetlands, grasslands in the Caribbean islands, and tropical and subtropical regions of North, Central, and South America (Chase \& Hobbs, 1969). This species has a key ecological role in the tropical coastal forest ecosystems, modifying soil properties with its digging activities (Quintero-Torre et al., 2018; Ridd, 1996), and affecting the seedling density and recruitment of the mangroves (Lindquist et al., 2009; Sherman, 2002). Therefore, the conservation of herbivorous land crabs should be included in management plans to maintain the forest structure, composition, and function (Lindquist et al., 2009).

Despite a steep decline in number over the past decades, likely due to habitat change and overexploitation (Govender, 2007; RodríguezFourquet \& Sabat, 2009), C. guanhumi still sustains a great deal of artisanal and commercial activity so that its harvest is both economically and culturally relevant (García-Quijano et al. 2015a, García-Quijano, et al. 2015b). However, an earlier perceived population decline related to a reduction in the reported landings provoked the Puerto Rico Department of Natural Environmental Resources (DNER) to regulate the species' capture by prohibiting the capture of gravid females by imposing an arbitrary size limit of $64 \mathrm{~mm}$ carapace width $(\mathrm{CW})$ for both sexes, and by establishing a temporary ban on the capture during the reproductive season of the crab (Reglamento de Pesca de Puerto Rico, 2010). Within the broader aim of generating basic biological information needed for the development of more sustainable exploitation of C. guanhumi in Puerto Rico, we studied the size structures and sex ratio in different areas and model the relative growth of body structures considered to be under sexual and fecundity selection with the ultimate aim to estimate the 
size at first maturity of both males and females. We discuss our results in contrast to the available information for the species and comparing the studied areas, suggesting changes to the parameters used by current local regulations.

\section{MATERIALS AND METHODS}

Sampling and study area: Sampling was conducted between 2001 and 2020 at nine different coastal locations around Puerto Rico, in the municipalities of Fajardo, Ceiba, Guánica, Cabo Rojo, Manatí, and Maunabo (Fig. 1). Each sampling event consisted of collecting crabs using traps set within fixed $10 \times 10 \mathrm{~m}$ plots established a priori with that aim, from now on referred to as "sampling sites" or only "sites." The traps were made of PVC pipes of different diameters $(4,5,8$, and $10 \mathrm{~cm})$ that allow the crabs to enter the tube and then block the exit with a lid (Fig. 2A). The traps were placed in all burrows present within the sampling site for approximately 12 hours from sunset to sunrise, corresponding to the hours of most activity of the land crab (Feliciano, 1962; Taissoun, 1974), except in Manatí where they remain for six hours. For all specimens, the sex was determined, and the following measurements were taken using a dial caliper to the nearest $\pm 0.1 \mathrm{~mm}$ : the males' and females' carapace width $(\mathrm{CW})$, major chela male's propodus length (PL), and female's fifth abdominal segment width (AW) (Fig. 2B).

There was only one sampling site per municipality, except in the two easternmost, Fajardo and Ceiba (latitudinally distant ca. 15 $\mathrm{km}$ from each other), in which two and three sampling sites were chosen respectively. The details of the sampling sites and periodicity are described below and summarized in Table 1 .

Reserva Natural Las Cabezas de San Juan is located in the Northeastern part of Puerto Rico in Fajardo. Two sampling sites, Redondel and Canalejo, are within the 178 ha of the reserve, where the mean annual temperature and precipitation are $25.6^{\circ} \mathrm{C}$ and $1709.2 \mathrm{~mm}$
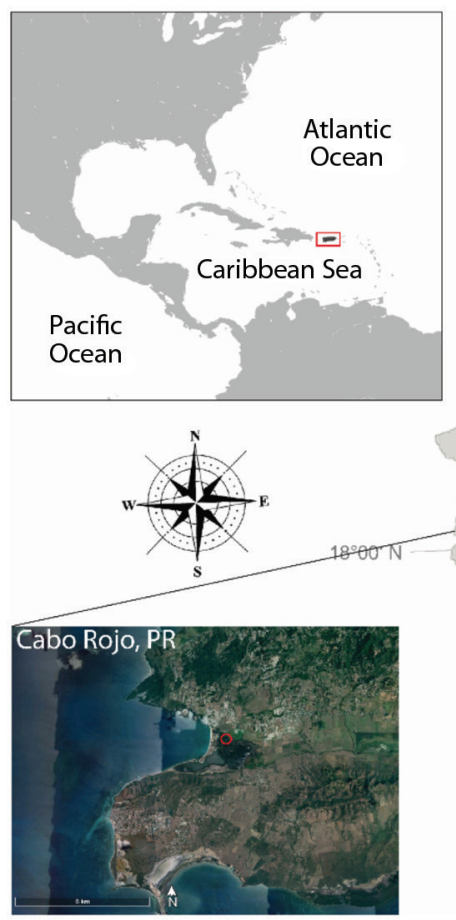
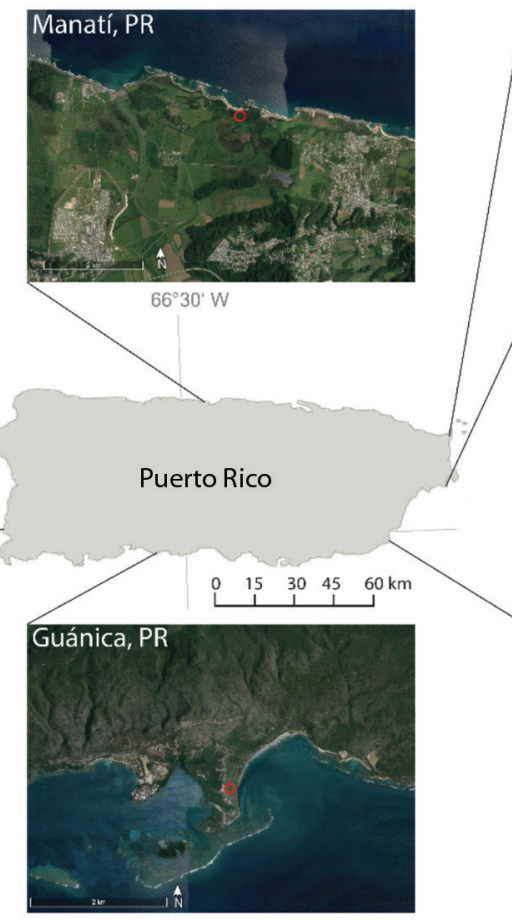
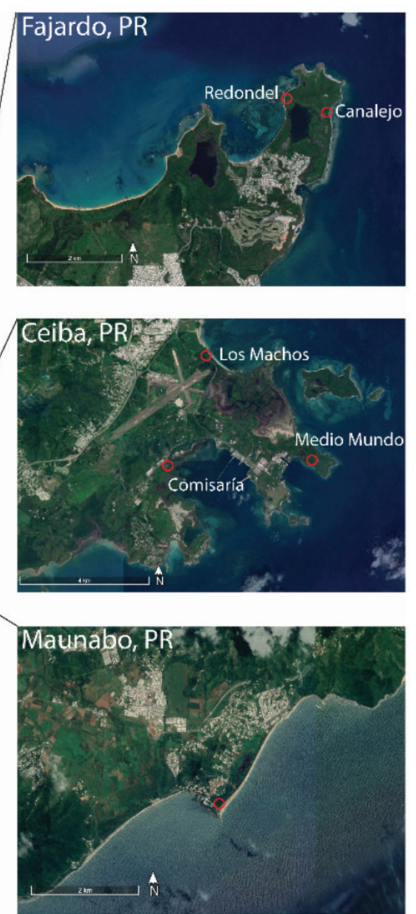

Fig. 1. Map of Puerto Rico, showing municipalities and sampling sites in this study. Satellite images retrieved from Google Earth (n.d.). 
A

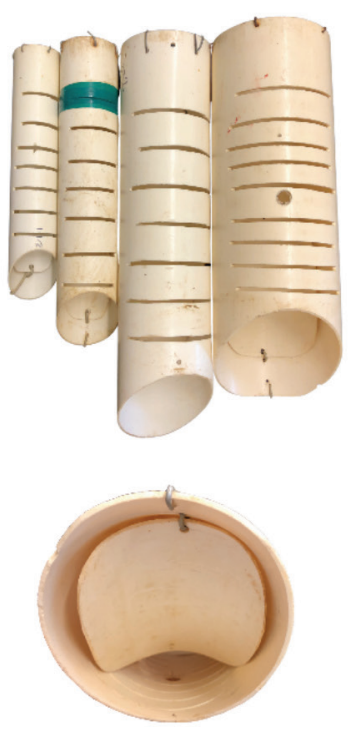

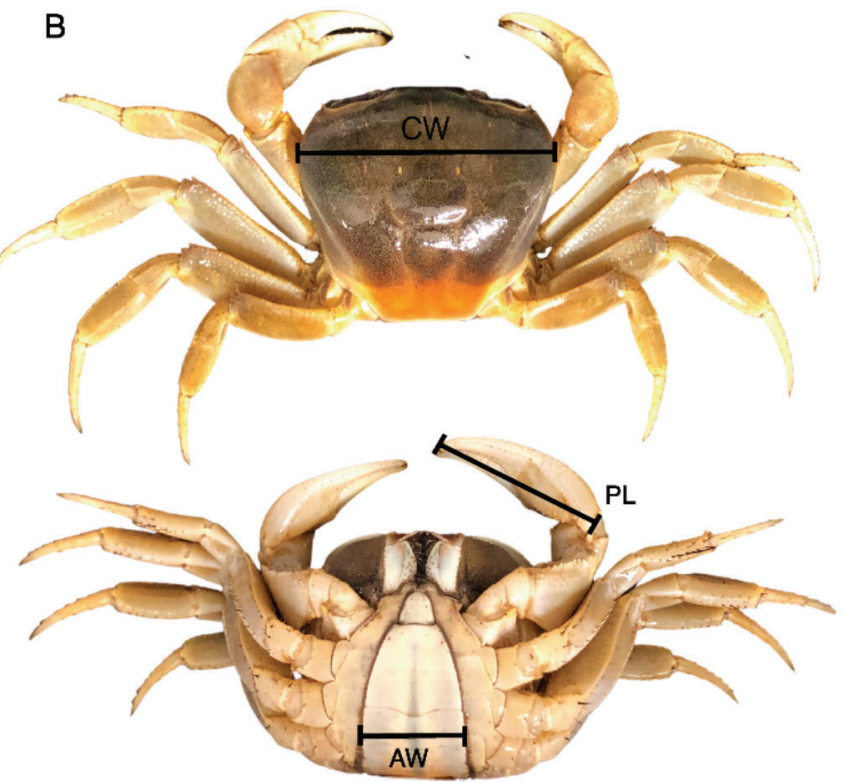

Fig. 2. A. Trap method used and B. Juvenile female of Cardisoma guanhumi showing where the morphometric measurements were taken. CW: Carapace Width, PL: Propodus Length in the major chela, AW: Abdomen Width.

TABLE 1

Numbers of individuals of Cardisoma guanhumi, sampling sites and collection and dates of collection

\begin{tabular}{llccc}
\hline \multicolumn{1}{c}{ Sampling site } & \multicolumn{1}{c}{ Dates } & Males & Females & Total \\
\hline Redondel & May 2001 - November 2002 and February 2020 & 412 & 373 & 785 \\
Canalejo & June 2001 - November 2002 & 41 & 66 & 107 \\
Comisaría & June 2001 - November 2002 & 71 & 69 & 140 \\
Los Machos & June 2001 - November 2002 & 58 & 61 & 119 \\
Guánica & December 2001 - November 2002 and July 2017 & 92 & 92 & 184 \\
Cabo Rojo & June 2001 - November 2002 and March 2020 & 188 & 203 & 391 \\
Manatí & April 2006 - February 2020 & 546 & 422 & 968 \\
Maunabo & December 2017 - April 2019 & 86 & 57 & 143 \\
Medio Mundo & July 2017 & 10 & 2 & 12 \\
Grand Total & & 1504 & 1345 & 2849 \\
\hline
\end{tabular}

Sampling was continuous between the time ranges specified except for Manati.

respectively (https://www.ncdc.noaa.gov/cdo$\mathrm{web} /$ ). Redondel is located $90 \mathrm{~m}$ inshore and has been used as barren land/pasture converted into a mangrove/coastal forest and has been a coastal forest for over 20 years. In turn, Canalejo is 13 meters away from the ocean and has been a coastal forest for over 80 years (Rodríguez-Fourquet, 2004).

Former United States Naval Station Roosevelt Roads is located in the Eastern part of
Puerto Rico in Ceiba. Three sampling sites, Comisaría, Playa Los Machos, and Medio Mundo y Daguao are within the 3480 ha where the mean annual temperature is 27.1 ${ }^{\circ} \mathrm{C}$ and mean annual precipitation is 1329.44 mm respectively (https://www.ncdc.noaa.gov/ cdo-web/). Comisaría is located $486 \mathrm{~m}$ inshore and is a swamp with marsh deposits with a land-use history that includes agriculture and pasture, secondary forest, military facility, and 
mangroves. Playa Los Machos is located $55 \mathrm{~m}$ from the ocean and has been a beach with dune deposits and mangrove forest for more than 85 years (Rodríguez-Fourquet, 2004). Medio Mundo y Daguao is a coastal forest located 195 $\mathrm{m}$ from shore.

Reserva Natural Punta Ballena is located in the Southwestern part of Puerto Rico in Guánica. This sampling site is located within the 65.9 ha reserve, where the mean annual temperature and precipitation are $24-28^{\circ} \mathrm{C}$ and $762 \mathrm{~mm}$, respectively (Guánica Dry Forest, unpublished data, 2004). This site is located at $534 \mathrm{~m}$ inshore and is a dry forest with abandoned plantation and secondary forest development. The land-use history includes barren land and mudflat (Rodríguez-Fourquet, 2004).

Refugio de Vida Silvestre de Boquerón is located in the Southwestern part of Puerto Rico in Cabo Rojo. This sampling site is located within 182 ha of the refuge, where the mean annual temperature and precipitation are 25.9 ${ }^{\circ} \mathrm{C}$ and $594 \mathrm{~mm}$, respectively (Boquerón Wildlife Refuge). This site is located $594 \mathrm{~m}$ from the Rincon Lagoon and is composed of dense forest mangrove. The land-use history of the area changed from agriculture to dense forest mangrove surrounded by an abandoned landfill and pastures (Rodríguez-Fourquet, 2004).

Reserva Natural Hacienda La Esperanza is located in the Northern part of Puerto Rico in Manatí. The reserve has an area of 898.5 ha where the mean annual temperature and precipitation are $25.0^{\circ} \mathrm{C}$ and $1443.48 \mathrm{~mm}$, respectively. The land-use history of the area has been sugar cane, pasture, and most recently, an increase in wetlands and coastal forest has been observed (Fideicomiso de Conservación de Puerto Rico, 2011).

Reserva Natural Humedal Punta Tuna is located in the Southeastern part of Puerto Rico in Maunabo. This sampling site is located within 43.2 ha of the refuge, where the mean annual temperature and precipitation are $26.6{ }^{\circ} \mathrm{C}$ and $1833.4 \mathrm{~mm}$, respectively. This site is located at $110 \mathrm{~m}$ inshore, and the land-use history of the reserve included swamps, agriculture, drainage of swampy areas, pasture, and coastal forest (Estudios Técnicos Inc., 2009).

Data analysis: The size structure was first visualized by building histograms separated by sex and location using carapace width as the variable for absolute size. Then sexual differences in size distributions were evaluated using Kernel Density Estimators (KDE) following Farias et al. (2014). This method allows knowing whether the differences are due to distributions' shapes, position, or both. A chi-square was also performed to identify differences in the sex ratio of each location, below and over the minimum legal size (MLS).

First, the whole morphometric dataset was pooled, and outliers were eliminated after confirming that they represented limb regenerations. Then the relative growth of selected body parts was modeled, and morphometric maturity was determined using the method developed by Watters and Hobday (1998) and used as in Farias et al. (2014). The method involves the use of smoothed splines instead of parametric models such as the classic two segment model of Somerton (1980) or the other available variations of it (Corgos \& Freire, 2006). The rationale behind using splines is to avoid fitting models on transformed data or based on a priori assumptions on the 'real' trajectory of the relative growth that may result in artificial breakpoints in the growth trajectories, misleading conclusions and estimations of the size at maturity (Farias et al., 2014, Farias et al., 2020; Packard, 2012). Briefly explained, the method consists in first 'binning' the bivariate data to create a new dataset with the values of the mean of each size class produced as the predictor variable and the median size of the body part of interest as the response variable. Then, a smoothed spline is fitted with degrees of freedom (d.f.) chosen based on a General Cross-Validation criterion. If the selected spline model is different from a straight line (have more than two d.f.), it is used to estimate the size at morphological sexual maturity by calculating the maximum point in its first derivative. This is made on the understanding that the 
first derivative of the relative growth trajectory represents the instantaneous growth rate for the average individual, so the maximum corresponds to the maximum rate of change in the relative growth of the selected body part. All the statistical analyses and the morphometric sexual maturity estimation were performed using the $\mathrm{R}$ software version 3.6.1 (R Core Team, 2016).

\section{RESULTS}

Size frequency distributions by sites and sex: A total of 2849 crabs were captured during the study period. Twelve crabs from Medio Mundo y Daguao were not included in the size-frequency distribution analysis because this site was sampled only once. Of the 2849 crabs, 1494 males and 1343 females (2 837 crabs) were used for the size-frequency distribution analyses. Most of the crabs (62\%) were captured in Redondel and Manatí (28 and $34 \%$ respectively). Most crabs in Redondel were below the MLS in contrast with Manatí (Fig. 3). Only in Manatí were all sizes well represented in the two sexes, ranging from 15.9 to $118.5 \mathrm{~mm} \mathrm{CW}$ in males and 15.4 to 106.6 $\mathrm{mm}$ in females. The remaining sites, with comparatively much fewer individuals sampled, had distributions skewed to sizes either smaller (Guánica, Cabo Rojo, and Maunabo) or larger (Canalejo, Los Machos, and Comisaría) than the MLS (red line in Fig. 3), and varied size range widths. Particularly, in Los machos and Canalejo, individuals smaller than $50 \mathrm{~mm} \mathrm{CW}$ were absent. In general, some sites presented smaller crab sizes than in others (e.g. Guánica, Redondel and Cabo Rojo), and in others juvenile crabs were not found (e.g. Canalejo and Los Machos).

Size frequency distributions were mostly unimodal but, in some cases, differed between sexes and/or among locations (Fig. 3). When the distributions were tested with the KDE test, the populations of Redondel, Canalejo, Maunabo and Manatí show a difference in the position of their distribution by sex (KDE test, $\mathrm{P}<$ 0.05, Fig. 3). Redondel, Canalejo and Manatí show larger males than females. Maunabo is an atypical case because it presents more small males than females and the largest number of individuals over $60 \mathrm{~mm}$ are female. The only population that presents differences in both position and distribution is Manatí. This population shows practically a normal distribution for females. However, the distribution of male crabs shows a slight skewness to smaller sizes, showing that most of the male crabs have carapace widths greater than $60 \mathrm{~mm}$. On the other hand, the populations of Cabo Rojo, Comisaría, Los Machos and Guánica do not present differences in position or the form of their distribution by sex (KDE test, $\mathrm{P}>0.05$, Fig. 3 ).

The sex ratio did not differ significantly between all populations $\left(\mathrm{X}^{2}=4.37\right.$, d.f. $=7, \mathrm{P}$ $=0.74)$. However, we found a significant difference in the sex ratio (1:1) within some populations. We found a difference over the MLS in the Redondel, Canalejo and Manatí populations (Table 2). The population of Redondel and Manatí has a greater number of males than females, while Canalejo shows a greater number of females. Also, a difference in sexual ratio was found below the MLS in Maunabo. This population shows a greater number of males below $64 \mathrm{~mm} \mathrm{CW}$. No differences were found in sex ratio in Los Machos, Comisaría, Guánica and Cabo Rojo (Table 2).

Relative growth and morphometric sexual maturity: Propodus and abdomen data were obtained from a total of 318 crabs (162 males and 156 females), which were analyzed to estimate the morphometric sexual maturity size of this species in Puerto Rico. In males, the carapace width and propodus measurements were used to estimate morphometric sexual maturity obtaining the best spline model fitted to the data with four d.f. (Fig. 4). Using this model, males show positive allometric growth $(b=1.31)$. The first derivative shows the increase in the growth velocity of the propodus in a constant way up to $80 \mathrm{~mm}$ carapace width approximately. The major change in relative growth for males occurred at $77.6 \mathrm{~mm}$ (95\% CI 57.9-79.0 $\mathrm{mm}$ ); this measurement 

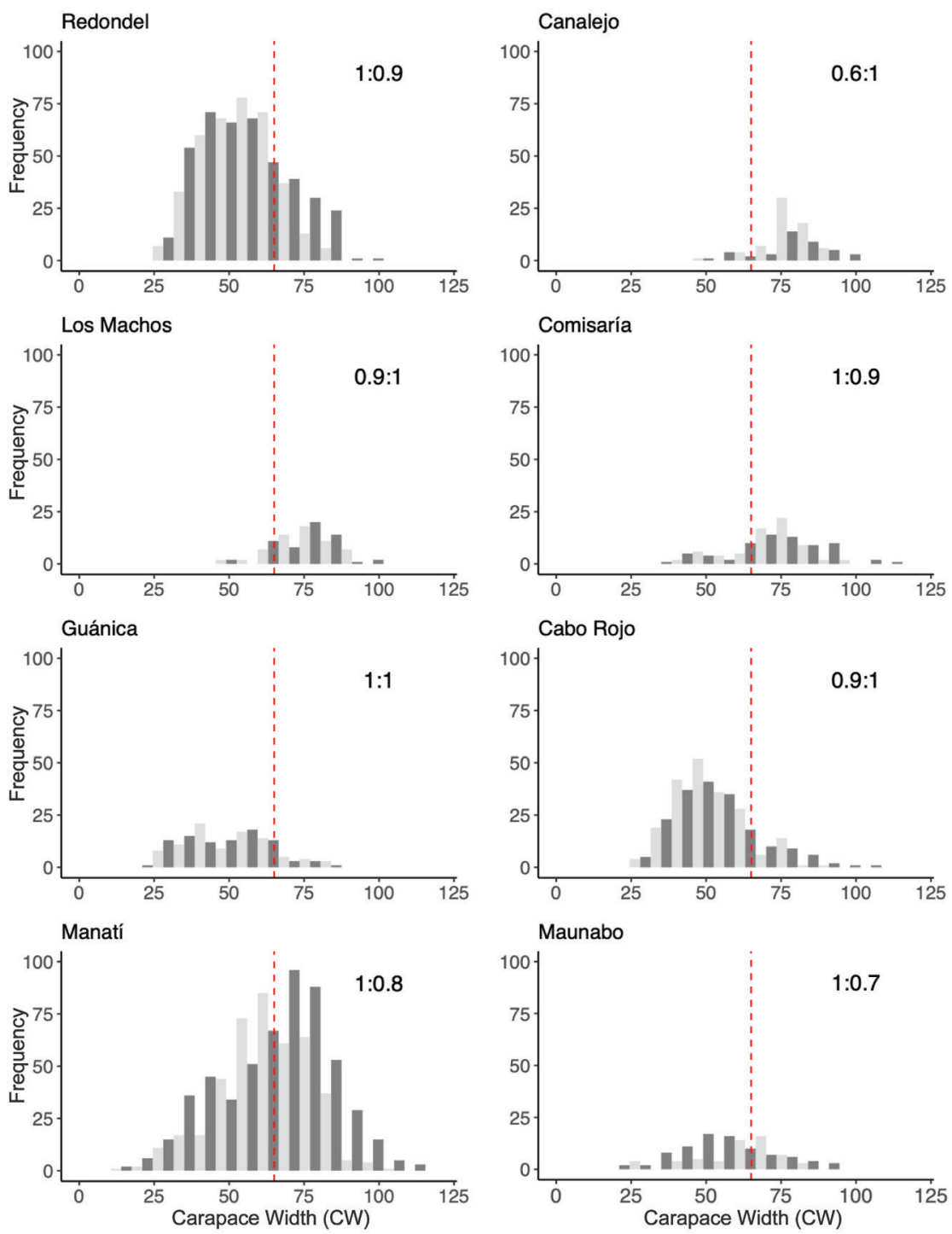

Fig. 3. Carapace width distributions for sampling sites in Puerto Rico. The sex ratio is shown in the upper right corner (Males:Females), and the red line shows the minimum legal size (MLS) in Puerto Rico (Dark Gray = Males, Light Gray $=$ Females).

corresponds to the mean size of morphometric sexual maturity.

In females, the carapace width and abdomen measurements were used to estimate the morphometric sexual maturity obtaining the best spline model with four d.f. (Fig. 4). The female abdomen also showed positive allometry $(b=1.36)$. The first derivative shows that the abdomen has an increase in growth velocity until it reaches approximately 60 $\mathrm{mm}$ carapace width, where it then begins to decrease. For females, the morphometric sexual maturity occurs at $47.2 \mathrm{~mm}(95 \% \mathrm{CI}$ 43.8-51.5 mm). Analysis of female abdomen growth shows a decrease in growth velocity starting at $30 \mathrm{~mm}$ carapace width. Female propodus growth is isometric $(b=1.07)$ with a best spline model with two d.f. This model was 
TABLE 2

Results obtained in the Chi-Square and Kernel Density Estimation (KDE)

\begin{tabular}{lcccccc}
\hline \multirow{2}{*}{ Site } & \multicolumn{4}{c}{ Chi-Square Test } & \multicolumn{2}{c}{ KDE Test (P) } \\
\cline { 2 - 5 } & \multicolumn{2}{c}{$\leq 64 \mathrm{~mm} \mathrm{CW}$} & \multicolumn{2}{c}{$>64 \mathrm{~mm} \mathrm{CW}$} & Position and Shape & Only Shape \\
\cline { 2 - 5 } Redondel & $\mathrm{X}^{2}$ & $\mathrm{P}$ & $\mathrm{X}^{2}$ & $\mathrm{P}$ & & \\
Canalejo & 0.015 & 0.901 & 9.092 & $0.003^{*}$ & $<0.001^{*}$ & $0.016^{*}$ \\
Comisaria & 1.600 & 0.206 & 8.670 & $0.003^{*}$ & $0.040^{*}$ & 0.854 \\
Los Machos & 0.053 & 0.819 & 0.160 & 0.689 & 0.052 & 0.482 \\
Guánica & 0.571 & 0.450 & 0.036 & 0.850 & 0.774 & 0.830 \\
Cabo Rojo & 0.312 & 0.576 & 1.815 & 0.178 & 0.490 & 0.740 \\
Manatí & 0.884 & 0.347 & 0.063 & 0.803 & 0.560 & 0.880 \\
Maunabo & 0.649 & 0.420 & 21.891 & $<0.001 *$ & $<0.001 *$ & $0.002^{*}$ \\
\hline
\end{tabular}

The chi-square evaluates differences in sexual ratio below and over the minimum legal size (MLS), and the KDE compares differences in the distribution by sex. *: Show significant differences.

not used for the determination of morphometric sexual maturity.

\section{DISCUSSION}

Size distribution and sex ratio: Unimodal size distributions such as those found here are common in decapod populations (Díaz \& Conde, 1989; García \& Mantelatto, 2001; Sastre, 1991; Spivak et al., 1991). However, marked differences in both the position and shape of the unimodal size structure are not frequent among populations sampled from different sites with similar environmental features, as is the case here. Skewed distributions lacking individuals of a particular size range reflect particular processes affecting the local demography, such as punctual recruitment and mortality events, sustained size-selective harvesting, or habitat segregation (Gulland \& Rosenberg, 1992). Populations of Comisaría, Los Machos, and Canalejo had mostly large individuals and no individuals below $40 \mathrm{~mm}$ $\mathrm{CW}$, indicating past very low or episodic recruitment and relatively high survival rates of large individuals (Rodríguez-Fourquet, 2004). In contrast, Redondel, Guánica, Cabo Rojo, and Maunabo had size-frequency distributions skewed to the right, showing a relative lack of adult crabs above the MLS, probably due to land-use change (Estudios Técnicos Inc., 2009; Rodríguez-Fourquet, 2004) aggravated by illegal harvesting (C. Rodríguez-Fourquet, personal observation, 2018).

Redondel and Canalejo, which are in the same reserve and less than $1 \mathrm{~km}$ apart, have contrasting size structures, which interestingly look complementary. It seems that the larger crab sizes, particularly the males, that are scarce in Redondel are well represented in the very close and well-connected site of Canalejo, suggesting habitat segregation by size for both sexes. Land use in Canalejo has not changed over the past 80 years, while Redondel suffered many land-use changes during that period as previously described. High habitat disturbance associated with land use might be the reason for the lack of larger crabs in Redondel. It has already been shown that larger crabs are more abundant in areas with lower disturbances and less historical land-use changes (Rodríguez-Fourquet, 2004; Rodríguez-Fourquet \& Sabat, 2009). Lastly, Manatí was the only sampling site where the size distribution structure resembled the normal distribution theoretically expected for populations of long-lived species with similar recruitment and mortality rates over time (Gulland \& Rosenberg, 1992). In 

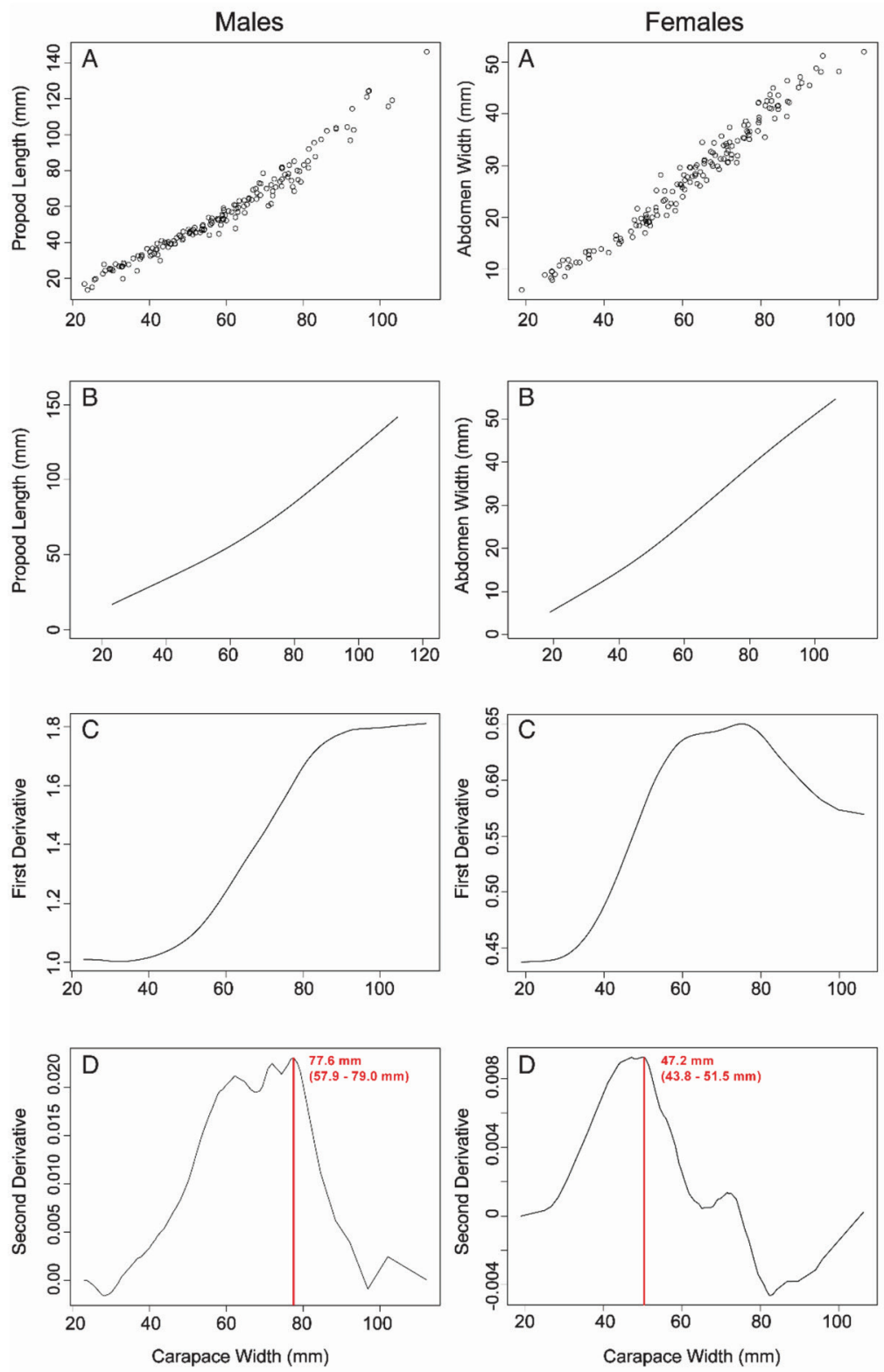

Fig. 4. Relative growth model and estimated morphometric sexual maturity for Cardisoma guanhumi in Puerto Rico. A. Original Data. B. Spline Model. C. First Derivative Plot. D. Second Derivative Plot with the sexual maturity size and 95 $\%$ confidence interval.

this area, land use has been mainly agricultural with minimum disturbance to coastal areas and no neighboring urban development (Fideicomiso de Conservación de Puerto Rico, 2011), conditions that seem to favor the stability of $C$. guanhumi populations at that site.
When comparing by sex, both the ratios and size distributions vary among sites in a manner that also seems to be resulting from differences in harvesting. Maunabo with a much smaller geographic extension than the other sites had experience many land-use changes 
throughout the years (Estudios Técnicos Inc., 2009). Based on field observations, we assume that the impact of harvesting is more significant than in other sites. In fact, during the sampling period, we found evidence of illegal harvesting, some of them reported following the DNER wildlife officers' intervention. The departure from the 1:1 sex ratio below MLS and the difference in sizes could indicate a sexselection harvesting effect where male crabs are more likely to be selected for their larger size as has been explained previously (Quiñones-Llópiz \& Rodríguez-Fourquet, 2019). At Maunabo, male crabs are more abundant in the smaller size classes while larger sizes are dominated by females. In some crab fisheries, it has been shown that if harvesting is heavily biased towards males (either because they are larger and thus more profitable, or because of arbitrary regulations based on the idea of maximizing egg availability), the sperm availability and quality can become a limiting factor for the effective reproduction and sustainability of the stock (Pardo et al., 2017; Sainte-Marie, 2007). The male-biased fishery can have significant implications for the reproductive biology of the species and consequently in the population survival. Manatí shows the same male-biased sex ratios; however, most crabs are sexually mature males capable of reproduction. Canalejo shows a female-biased sex ratio, possibly because this study area is very close to the sea, allowing easy access to the water for larval release during the reproductive season.

Given the wide variation in the size structures we observed, even between very similar and close sites, it is evident that monitoring the populations over time can be informative. The monitoring will provide information about the natural demographic processes of the species that are not yet properly known, the degree of exploitation, and habitat recovery. This becomes very useful data in the current context of unreported artisanal and personal consumption extraction that limits the access to the catch effort data required for management decisions.

\section{Sexual maturity using relative growth:} The relative growth of the land crab Cardisoma guanhumi has been studied previously on populations in Florida, USA, showing sexual dimorphism (Gifford, 1962; Herreid, 1967). As previously described, the species present heterochely in both males and females, but males develop larger chelae in relation to body size. In crabs, heterochely and sexual differences in claw size are thought to be associated with the multiplicity of functions played by the chelae and the differences in use by sex, such as in defense, feeding, intra-sex antagonisms, courtship display, burrowing, mate guarding, and pair manipulation during copula (Daleo et al., 2009; Yamaguchi et al., 2005). In some land crab species, such as most fiddler crabs, the drivers for the development of sexual differences in relative growth of the chelae are well understood because of their role on male's courtship, defense of the territory, and combat (Crane, 2015). However, in C. guanhumi, the specific function of the major chela was not studied in depth, although it was suggested that it has implications in social behavior (Herreid, 1967). The male size at sexual maturity found in this study is close to that reported in the literature for other regions in the continent (Herreid, 1967; Shinozaki-Mendes et al., 2013). The higher acceleration rate of propodus growth indicates the moment the crab reaches maturity. During growth, male crabs invest much energy in gonadal development, and once their gonads mature, they can invest energy in the growth of other organs. This difference occurs after the prepubertal molt, previously described by Teissier (1960).

Females also present heterochely as discussed above. However, the isometric growth of the propodus with respect to carapace width makes it impossible to estimate the size of sexual maturity. The model used in this study permits estimating tipping points in the ontogenic trajectory of the relative growth only if it is significantly different from a straight line. Females often show allometrically positive 
growth of the abdomen during gonadal maturation and then a decrease in growth acceleration when they reach puberty (Hartnoll, 1988). The morphometric size at sexual maturity based on the abdomen found in this study is smaller than most previously reported in the literature (Botelho et al., 2001; Shinozaki-Mendes et al., 2013; Silva et al., 2014). However, the methods used differ among studies. Also, the size of sexual maturity may vary by location because growth in crabs is limited by several factors, for example, availability of water and food (Hirose et al., 2013; Spivak et al., 2016; Wolcott, 1988).

The exploitation of natural populations with a strong bias towards the removal of the largest individuals may lead to changes in the mean values of some life history and other features of the harvested population, e.g. the size at first maturity, maximum size and sex ratios. In particular, a reduction in the size at maturity due to size biased harvesting has been observed in variety of species form different taxa, including true crabs (e.g. Chionoecetes bairdi) (Edeline et al., 2007; Grift et al., 2003; O'Dea et al., 2014; Zheng, 2008). Therefore, the difference observed in the size at sexual maturity of the females compared to other regions can be an indication of the intense harvesting pressure that the species is experiencing in Puerto Rico. Early maturity increases the probability that the population will reproduce, at least once before being captured, in response to exploitation on the island. Regulation in Puerto Rico allows the capture of females that are non-ovigerous and exceeding a minimum size of $64 \mathrm{~mm}$ carapace width (Reglamento de Pesca de Puerto Rico, 2010). In practice, however, it is known that egg-bearing females are routinely caught due to the lack of proper control in the field and their higher value, as the egg masses are considered a culinary delicacy, increasing the possibility of changes in the life history of this species.

Implications and Recommendations: Current regulations in Puerto Rico afford protection to the female crabs but not to larger male crabs. The regulation establishes that crabs smaller than $64 \mathrm{~mm}$ carapace width cannot be captured. Therefore, the whole range of female sizes reaching morphometric sexual maturity is protected (range 43.8 to $51.4 \mathrm{~mm}$ $\mathrm{CW}$ ). However, males that reach sexual maturity at a larger size are not protected by this regulation. The higher limit of the confidence interval of the morphometric sexual maturity is $79.0 \mathrm{~mm}$ carapace width (range 57.9 to 79.0 $\mathrm{mm}$ carapace width), indicating that sexually immature male crabs are legally captured under current regulations. This could have significant implications for the reproduction of the species and, therefore, for the conservation of its populations on the island. We suggest considering different size limits depending on the sex of the crab. Based on our estimates of morphometric sexual maturity for C. guanhumi in Puerto Rico, we recommend that the minimum commercial size be $60 \mathrm{~mm} \mathrm{CW}$ for females and $80 \mathrm{~mm} \mathrm{CW}$ for males. This will allow the full range of sizes where sexual maturity is reached to be protected, increasing the likelihood of the population's size to increase.

Knowing the ecological, cultural, and economic importance of this species and the minimal information that exists, research and mitigation efforts should be increased on the island. Immediate measures should be imposed to ensure the protection of populations of this species as well as the habitat. We recommend this effort to go with an educational component that informs the public and community about the importance of this species to the coastal ecosystems in Puerto Rico and the danger they face. More research about the ecology, reproduction and physiological sexual maturity combined with the regulations will safeguard the populations of $C$. guanhumi for future generations.

Ethical statement: authors declare that they all agree with this publication and made significant contributions; that there is no conflict of interest of any kind; and that we followed all pertinent ethical and legal procedures and requirements. All financial sources are fully and clearly stated in the acknowledgements 
section. A signed document has been filed in the journal archives.

\section{ACKNOWLEDGMENTS}

Funding for this project came from different sources throughout the years: Sea Grant College Program, Mayaguez, Puerto Rico Grant \# PD-225R/L.b.-31. Para La Naturaleza, Puerto Rico Department of Natural and Environmental Resources, University of Puerto Rico at Bayamon, University of Puerto Rico at Rio Piedras, Puerto Rico Louis Stokes Alliance for Minority Participation. We want to thank the Universidad de Mar del Plata, Argentina and the Instituto de Investigaciones Marinas y Costeras (CONICET) in Mar del Plata. We also want to thank all the undergraduate and graduate students, citizen scientists, Comité ProDesarrollo de Maunabo, friends and colleagues that participated in data gathering in the field, data entry, data analysis and discussions, and also to all the anonymous reviewers for their valuable comments to improve this manuscript.

\section{RESUMEN}

\section{Distribución de tallas y proporción de sexos entre poblaciones del cangrejo de tierra cosechado artesanalmente Cardisoma guanhumi \\ (Decapoda: Gecarcinidae), con la estimación del crecimiento relativo y tamaño en la madurez sexual en Puerto Rico}

Introducción: El conocimiento de los patrones de crecimiento, la proporción de sexos y la madurez sexual son de suma importancia para las poblaciones explotadas. El cangrejo terrestre Cardisoma guanhumi es una especie explotada artesanalmente y para subsistencia en Puerto Rico. Sin embargo, se desconocen los patrones de crecimiento y la madurez sexual para la isla.

Objetivos: Este estudio tiene un doble objetivo: (1) comparar el tamaño y la estructura sexual entre las poblaciones y (2) modelar el crecimiento relativo de estructuras relacionadas con la reproducción (propodo en machos y abdomen en hembras) para estimar el tamaño promedio de madurez sexual morfométrica (MSM).

Métodos: Se capturaron un total de 2849 especímenes de nueve poblaciones dispersas en la isla, entre 2001 y 2020 Se midió el ancho del caparazón (AC) como un estimador del tamaño absoluto de todos los individuos, junto con el largo de propodo en los machos y el ancho del abdomen en las hembras. Las diferencias en la estructura de tallas entre sexos y poblaciones se probaron aplicando la prueba de bondad de ajuste basado en estimaciones de densidad kernel (KDE). El patrón de crecimiento relativo se modeló ajustando un spline a partir del cual se calculó el máximo de su segunda derivada como estimador del MSM y se utilizó bootstrapping para generar intervalos de confianza.

Resultados: Se encontraron diferencias en las estructuras de tallas, entre sexos y poblaciones. Nuestras estimaciones de madurez sexual morfométrica dieron como resultado un tamaño de madurez sexual para los machos entre 57.9 y $79.0 \mathrm{~mm} \mathrm{AC}$, mientras que, en las hembras, la madurez morfométrica se produce entre 43.8 y $51.5 \mathrm{~mm} \mathrm{AC}$.

Conclusiones: La diferencia en el tamaño de la población se puede atribuir a las diferencias entre poblaciones en el cambio de uso de la tierra y la presión de explotación asociada con el sesgo hacia la captura de individuos más grandes o el reclutamiento. Las regulaciones actuales en Puerto Rico brindan protección a las hembras, pero no a los machos más grandes. El reglamento establece que no se pueden capturar cangrejos de menos de $64 \mathrm{~mm}$ de AC dejando desprotegidos los cangrejos machos inmaduros de más de 64 mm AC. Sugerimos considerar diferentes límites de tamaño según el sexo del cangrejo. Esto permitirá proteger un rango más amplio de tamaños donde se alcanza la madurez sexual, aumentando la probabilidad de un incremento en el tamaño de la población.

Palabras clave: biología reproductiva; juey; mangle; cambio de uso de tierra; pesquerías; recomendaciones de manejo.

\section{REFERENCES}

Botelho, E. R. O., Santos, M. F., \& Souza, J. R. B. (2001). Aspectos populacionaisdo Guaiamum, Cardisoma guanhumi Latreille 1825, do estuário do Rio Una (Pernambuco-Brasil). Boletim Técnico Científico CEPENE, 9(1), 123-146.

Chase Jr., F., \& Hobbs Jr., H. H. (1969). The freshwater decapod crustacean of the West Indies with Special Reference to Dominica. Bulletin of the United States National Museum, 292.

Corgos, A., \& Freire, J. (2006). Morphometric and gonad maturity in the spider crab Maja brachydactyla: a comparison of methods for estimating size at maturity in species with determinate growth. ICES Journal of Marine Science, 63(5), 851-859.

Crane, J. (2015). Fiddler crabs of the world: Ocypodidae: genus Uca (Vol. 1276). Princeton University Press.

Daleo, P., Luppi, T., Casariego, A. M., Escapa, M., Ribeiro, P., Silva, P., \& Iribarne, O. (2009). The effect of size and cheliped autotomy on sexual competition between males of the mud crab Cyrtograpsus angulatus Dana. Marine Biology, 156(3), 269-275. 
Díaz, H., \& Conde, J. E. (1989). Population dynamics and life history of the mangrove crab Aratus pisonii (Brachyura, Grapsidae) in a marine environment. Bulletin of Marine Science, 45(1), 148-163.

Edeline, E., Carlson, S. M., Stige, L. C., Winfield, I. J., Fletcher, J. M., James, J. B., Haugen, T. O., Asbjom, L., \& Stenseth, N. C. (2007). Trait changes in a harvested population are driven by a dynamic tug-of-war between natural and harvest selection. Proceedings of the National Academy of Sciences, 104(40), 15799-15804.

Estudios Técnicos Inc. (2009). Plan de Manejo Reserva Natural del Humedal Punta Tuna. Maunabo, Puerto Rico.

Farias, N. E., Bas, C., Kittlein, M. J. (2020). Growth and sexual maturity. In T. A. Luppi, \& E. M. Rodríguez (Eds.), Neohelice granulata, a Model Species for Studies on Crustaceans. Volume I, Life History and Ecology (pp. 137-158). Cambridge Scholars Publishing.

Farias, N. E., Luppi, T. A., \& Spivak, E. D. (2014). Habitat use, relative growth and size at maturity of the purple stone crab Platyxanthus crenulatus (Decapoda: Brachyura), calculated under different models. Scientia Marina, 78(4), 567-578.

Feliciano, C. (1962). Notes on the biology and economic importance of the land crab Cardisoma guanhumi, Latreille of Puerto Rico. Department of Agriculture of Puerto Rico.

Fideicomiso de Conservación de Puerto Rico. (2011). Plan de Manejo de la Reserva Natural Hacienda La Esperanza. Manatí, Puerto Rico.

García, R. B., \& Mantelatto, F. L. (2001). Population dynamics of the hermit crab Paguristes erythrops (Diogenidae) from Anchieta Island, southern Brazil. Journal of the Marine Biological Association of the United Kingdom, 81(6), 955.

García-Quijano, C. G., Poggie, J. J., \& Del Pozo, M. H. (2015a). En el monte también se pesca: "Pesca de monte", ambiente, subsistencia y comunidad en los bosques costeros del sureste de Puerto Rico. Caribbean Studies, 43(2), 115-144.

García-Quijano, C. G., Poggie, J. J., Pitchon, A., \& Del Pozo, M. H. (2015b). Coastal resource foraging, life satisfaction, and well-being in southeastern Puerto Rico. Journal of Anthropological Research, 71(2), 145-167.

Gifford, C. A. (1962). Some observations on the general biology of the land crab, Cardisoma guanhumi (Latreille), in south Florida. The Biological Bulletin, 123(1), 207-223.

Google Earth (n.d.). Satellite images from Puerto Rico Island, USA. https://www.google.com/earth/
Govender, Y. (2007). A multidisciplinary approach towards understanding the distribution, abundance and size structure of the land crab Cardisoma guanhumi (Latreille, 1825) in two estuaries in Puerto Rico (Doctoral dissertation). University of Puerto Rico, Rio Piedras, Puerto Rico.

Grift, R. E., Rijnsdorp, A. D., Barot, S., Heino, M., \& Dieckmann, U. (2003). Fisheries-induced trends in reaction norms for maturation in North Sea plaice. Marine Ecology Progress Series, 257, 247-257.

Guánica Dry Forest. (2004). Historical abiotic factors in the reserve. [Unpublished data].

Gulland, J. A., \& Rosenberg, A. A. (1992). A review of length-based approaches to assessing fish stocks (Technical Paper. No. 323). FAO Fisheries.

Hartnoll, R. G. (1978). The Determination of Relative Growth in Crustacea. Crustaceana, 34(3), 281-293.

Hartnoll, R. G. (1988). Growth and Molting. In W. Burggren, \& B. McMahon (Eds.), Biology of the Land Crabs (pp. 186-210). Cambridge University Press.

Hartnoll, R. G. (2012). Relative growth: description and analysis. In J. Forest, \& C. V. Klein (Eds.), Treatise on Zoology-Anatomy, Taxonomy, Biology. The Crustacea (Vol. 3, pp. 365-401). Brill.

Herreid, C. F. (1967). Skeletal measurements and growth of the land crab, Cardisoma guanhumi Latreille. Crustaceana, 13(1), 39-44.

Hirose, G. L., Fransozo, V., Tropea, C., López-Greco, L. S., \& Negreiros-Fransozo, M. L. (2013). Comparison of body size, relative growth and size at onset sexual maturity of Uca uruguayensis (Crustacea: Decapoda: Ocypodidae) from different latitudes in the southwestern Atlantic. Journal of the Marine Biological Association of the United Kingdom, 93(3), 781-788.

Lindquist, E. S., Krauss, K. W., Green, P. T., O’Dowd, D. J., Sherman, P. M., \& Smith III, T. J. (2009). Land crabs as key drivers in tropical coastal forest recruitment. Biological Reviews, 84(2), 203-223.

Lovett, D. L., \& Felder, D. L. (1989). Application of regression techniques to studies of relative growth in crustaceans. Journal of Crustacean Biology, 9(4), 529-539.

Magnuson-Stevens Fishery Conservation and Management Act, 16 U.S.C. $§ 1801$ (2014). https://www. congress.gov/bill/113th-congress/senate-bill/2991/ text? $r=1 \& \mathrm{~s}=1$

O’Dea, A., Shaffer, M. L., Doughty, D. R., Wake, T. A., \& Rodriguez, F. A. (2014). Evidence of size-selective evolution in the fighting conch from prehistoric subsistence harvesting. Proceedings of the Royal Society B: Biological Sciences, 281(1782), 20140159. 
Olson, A. P., Siddon, C. E., \& Eckert, G. L. (2018). Spatial variability in size at maturity of golden king crab (Lithodes aequispinus) and implications for fisheries management. Royal Society Open Science, 5(3), 171802 .

Packard, G. C. (2012). Julian Huxley, Uca pugnax and the allometric method. Journal of Experimental Biology, 215(4), 569-573.

Pardo, L. M., Riveros, M. P., Fuentes, J. P., Pinochet, R., Cárdenas, C., \& Sainte-Marie, B. (2017). High fishing intensity reduces females' sperm reserve and brood fecundity in a eubrachyuran crab subject to sex-and size-biased harvest. ICES Journal of Marine Science, 74(9), 2459-2469.

Pikitch, E. K., Santora, C., Babcock, E. A., Bakun, A., Bonfil, R., Conover, D. O., Dayton, P., Fluharty, D., Heneman, B., Houde, E. D., Link, J., Livingston, P. A., Mangel, M., McAllister, M. K., Pope, J., \& Sainsbury, K. J. (2004). Ecosystem-based fishery management. Science, 305(5682), 346-347

Quintero-Torres, E., Chacón, N., \& López-Sánchez, B. (2018). The ecosystem engineering role of the Neotropical crab Cardisoma guanhumi on mangrove soil properties. Wetlands Ecology and Management, 26(5), 993-1000.

Quiñones-Llópiz, J. D., \& Rodríguez-Fourquet, C. (2019). Dinámica y estructura de la población del cangrejo terrestre Cardisoma guanhumi (Latreille, 1825) en la Reserva Natural del Humedal Punta Tuna en Maunabo, Puerto Rico. Manglares de América, 98-110.

R Core Team. (2016). R: A language and environment for statistical computing. R Foundation for Statistical Computing. Vienna, Austria. https://www.R-project. org/

Reglamento de Pesca de Puerto Rico no. 7949. (2010). Departamento de Recursos Naturales y Ambientales, Gobierno de Puerto Rico. https://www.drna.pr.gov/ reglamentos/reglamento-num-7949

Ridd, P. V. (1996). Flow through animal burrows in mangrove creeks. Estuarine, Coastal and Shelf Science, 43(5), 617-625.

Rodriguez-Fourquet, C. (2004). Abundance and demography of Cardisoma guanhumi in Puerto Rico (Doctoral dissertation). University of Puerto Rico, Rio Piedras, Puerto Rico.

Rodríguez-Fourquet, C., \& Sabat, A. M. (2009). Effect of harvesting, vegetation structure and composition on the abundance and demography of the land crab Cardisoma guanhumi in Puerto Rico. Wetlands Ecology and Management, 17(6), 627-640.
Sainte-Marie, B. (2007). Sperm demand and allocation in decapod crustaceans. In E.E. Duffy, \& M. Thiel (Eds.), Evolutionary ecology of social and sexual systems: crustaceans as model organisms (pp. 191-210). Oxford University Press.

Sastre, M. P. (1991). Sex-specific growth and survival in the mole crab Emerita portoricensis (Schmitt). Journal of Crustacean Biology, 11(1), 103-112.

Sherman, P. M. (2002). Effects of land crabs on seedling densities and distributions in a mainland neotropical rain forest. Journal of Tropical Ecology, 18(1), 67-89.

Shinozaki-Mendes, R. A., Silva, J. R. F., Santander-Neto, J., \& Hazin, F. H. V. (2013). Reproductive biology of the land crab Cardisoma guanhumi (Decapoda: Gecarcinidae) in north-eastern Brazil. Journal of the Marine Biological Association of the United Kingdom, 93(3), 761.

Silva, C. C., Schwamborn, R. C., \& Oliveira, J. E. (2014). Population biology and color patterns of the blue land crab, Cardisoma guanhumi (Latreille 1828) (Crustacea: Gecarcinidae) in the Northeastern Brazil. Brazilian Journal of Biology, 74(4), 949-958.

Somerton, D. A. (1980). A computer technique for estimating the size of sexual maturity in crabs. Canadian Journal of Fisheries and Aquatic Sciences, 37(10), 1488-1494.

Spivak, E. D., Bas, C. C., \& Luppi, T. A. (2016). Great unexpected differences between two populations of the intertidal crab Neohelice granulata inhabiting close but contrasting habitats (Crustacea: Decapoda: Brachyura). Zoologia (Curitiba), 33(6), e20160020

Spivak, E. D., Gavio, M. A., \& Navarro, C. E. (1991). Life history and structure of the world's southernmost Uca population: Uca uruguayensis (Crustacea, Brachyura) in Mar Chiquita Lagoon (Argentina). Bulletin of Marine Science, 48(3), 679-688.

Taissoun, E. (1974). El cangrejo de tierra Cardisoma guanhumi (Latreille) en Venezuela: distribución, ecología, biología y evaluación poblacional. Universidad del Zulia, Consejo de Desarrollo Científico y Humanístico--CONDES, Facultad de Humanidades y Educación, Centro de Investigaciones Biológicas.

Teissier, G. (1960). Relative growth. In T. H. Waterman (Ed.), The Physiology of Crustacea (Vol. 1, pp. 537-560). Academic Press.

Townsend, H., Harvey, C. J., deReynier, Y., Davis, D. Zador, S. G., Gaichas, S., Weijer-man, M., Hazen, E. L., \& Kaplan, I. C. (2019). Progress on implementing ecosystem-based fisheries management in the United States through the use of ecosystem models and analysis. Frontiers in Marine Science, 6, 641. 
Watters, G., \& Hobday, A. J. (1998). A new method for estimating the morphometric size at maturity of crabs. Canadian Journal of Fisheries and Aquatic Sciences, 55(3), 704-714.

Wolcott, T. (1988). Ecology. In W. Burggren, \& B. McMahon (Eds.), Biology of the Land Crabs (pp. 55-96). Cambridge University Press.
Yamaguchi, T., Ogata, R., \& Henmi, Y. (2005). Sexual differences of the feeding claws and mouthparts of the fiddler crab, Uca arcuata (De Haan, 1833) (Brachyura, Ocypodidae). Crustaceana, 78(10), 1233-1263.

Zheng, J. (2008). Temporal changes in size at maturity and their implications for fisheries management for eastern Bering Sea Tanner crab. Journal of Northwest Atlantic Fishery Science, 41, 137-149. 